\title{
The Existential Relevance of Art for Human Life
}

\author{
Giovanna Caruso \\ giovanna.caruso@uni-greifswald.de
}

\begin{abstract}
What is the relevance of art for human life? This question can be answered if life is understood from life-performance and art from artworks. From this perspective, the human being - understood as a being in a self-researching process - and the work of art - conceived as an experience-figure - show a structural correspondence: a constitutive unfathomability. Both, human being and art, can only be adequately understood as open processes of their respective selfrealization. Because of this correlation and, at the same time, considering their fundamental difference, the aesthetic experience enables the human being to objectify the process of self-research. Thus, the existential relevance of art to life becomes concrete in that the aesthetic experience that makes the artwork the unique unfathomability that it is, reveals itself as an excellent path to the process of self-research, which makes human beings the unique unfathomability that he or she is.
\end{abstract}

Keywords: artwork, self-realization-process, experience-figure, unfathomability. 


\title{
The Existential Relevance of Art for Human Life
}

\author{
Giovanna Caruso \\ giovanna.caruso@uni-greifswald.de
}

\section{Introduction}

Questions about the nature of art and its role in human life have accompanied Western thought since its origins. In view of the current aesthetic debate, however, this question seems out of date. Art and life are considered to be two research areas in different disciplines, whose research interests sometimes coincide, but between which there is no necessary connection. The question of the function, the meaning, the role of art in life was present in the aesthetic theories of the first half of the last century. In this sense, Martin Heidegger, Theodor W. Adorno, Walter Benjamin and Maurice Merleau-Ponty, for examples, developed conceptions of art in which the relationship between art and life is a constitutive component. The essentialist art theories at the beginning of the century also, more or less explicitly, express the meaning of art for life. Nowadays this question seems to have become outdated within a pluralistic, innovative and even provocative artistic panorama it sounds too traditionalistic and conservative. In fact, this question no longer plays a role in the current aesthetic debate, neither in Englishspeaking countries nor in Central Europe.

This finding may not seem surprising in relation to aesthetic research in Englishspeaking countries because it traditionally coincides with questions about the essence, the nature and the possibilities of the definition of the work of art. Although in recent years historical-narrative theories ${ }^{1}$ have taken existentialist aspects into account and have overcome the one-sidedness of the linguistic-analytical approaches of the 50 's $\mathrm{s}^{2}$ and

\footnotetext{
1 N.E. Carroll, Historical Narratives and the Philosophy of Art, in "Journal of Aestehtics and Art Criticism, 51, 1993, pp. 313-326; J. Levinson, Extending Art Historically, in "Journal of Aesthetics and Art Criticism", 51, 1993, pp. 411-423.

${ }^{2}$ New Wittgensteinians Theories: M. Weitz, The Role of Theory in Aesthetic, in "Journal of Aesthetics and Art Criticism", 15, 1956, pp. 27-35; W. Kennick, Does Traditional Aesthetics Rest on a Mistake, in
} 
the debate about the art-properties ${ }^{3}$ in the second half of the last century, aesthetic research continues to understand itself exclusively as a theory of art.

The ascertained lack of interest in aesthetic research for life in the Central European world can, however, be surprising and perhaps even inadequate. In recent years there has been an expansion of the research interest in aesthetics, which now takes into account the metamorphosis of aesthetics ${ }^{4}$, which, on the one hand, is concretized in the attempt to understand and explain the new developments in aesthetic and artistic practice. On the other hand, it concentrates on processes of aestheticization in nonaesthetic areas such as nature, politics and the economy, i.e. on a phenomenon that Rüdiger Bubner and many others authors after him described as an unstoppable process of aestheticization of the lifeworld ${ }^{5}$. And if, on the one hand, the strong reference to the lifeworld seems to restore and guarantee that connection between art and life, which was loosened in the last years of the century, on the other hand, precisely that process of aestheticization of all areas of the real and the life which - radically understood - does not recognize the uniqueness of the work of art.

In this perspective, in which everything counts or can count as art and in which the difference between the aesthetic and the non-aesthetic shrinks to the point of disappearing, the question of the relationship between art and life loses its meaning. A distinction between the two terms, has become impossible and is now mixed and almost interchangeable.

In the light of this diagnosis, the present article represents an attempt to redirect the attention of aesthetic research to the relationship between art and life. Therefore, the central question of the following study is: What is the relevance of art for human life? This question goes beyond the research interests of the aesthetic debate in both English-

\footnotetext{
“Mind", 67, 1958, pp. 317-334; P. Ziff, The Task of Defining a Work of Art, in "Philosophical Review", 62,1953, pp. 58-78.

${ }^{3}$ F. Sibley, Aesthetic Concepts, in "The Philosophical Review”, 68/4, 1959, pp. 421-450; Gary Stahl, Sibley's "Aesthetic Concepts": An Ontological Mistake, in "The Journal of Aesthetics and Art Criticism", 29, 1971, pp. 385-389; A.C. Danto, Artworks and Real Things, in "Theoria", 39/1 3, 1973, pp. 1-17; J. Levinson, Being Realistic about Aesthetic Properties, in "The Journal of Aesthetics and Art Criticism", 52/3, 1994, pp. 351-354; D. Matravers, J. Levinson, Aesthetic Properties, in "Proceedings of the Aristotelian Society, Supplementary Volumes", 79, 2005, pp. 191-227.

${ }^{4}$ Title of the XIX National Conference of the SIE (Italian Society of Aesthetics).

5 G. Böhme, Atmosphäre. Essays zur neuen Ästhetik, Suhrkamp, Frankfurt am Main 2013; R. Bubner, Ästhetische Erfahrung, Suhrkamp, Frankfurt am Main 1989; W. Welsch, Ästhetisches Denken, Reclam, Stuttgart 1990.
} 
speaking and Central European countries. That is precisely why it presents itself as the possibility of a meeting point between the two traditions. On the one hand, by finding oneself forced to work out a definition of art, it contributes to the English-language debate. On the other hand, by dealing with art in relation to life, it will deal with existentialist aspects that traditionally characterize the European debate about art.

Considering the current aesthetic debate about art in the two traditions, the question about the relevance of art for life seems not only difficult to answer but also paradoxical. In fact, on the one hand, art is a research object of different, sometimes contradictory theories, which not only offer different definitions of art, but point out the indefinability of artistic practice and the artwork $^{6}$. On the other hand, questions regarding the human being are also taken up and answered in many ways so that subject-specific incompatible definitions of the human being and life arise. If this diversity seems to correspond to the pluralism of the current world, it gives rise to the idea that a unified characterization of human being is impossible ${ }^{7}$. Art and human life, then, emerge as phenomena that either cannot be defined at all, or can only be defined relativistically. If so, the attempt to disclose the existential importance of art for life would either result in a trivial effort to connect two indefinable phenomena, or in a banal project designed to renounce any claims of objectivity and universality.

My paper opposes this alternative and shows that the question of the existential importance of art for life can be asked and answered systematically. This becomes possible by thinking about life as a life-performance of the individual human being, and about art starting from the work of art. In this sense, according to philosophical anthropology, the human being is defined as the only ever conscious process of selfresearch; the artwork, on the other hand, - in light of the most recent art theories, which emphasize the singularity of each work of art - is conceived as an experience-figure. This intrinsic access to life and art will show that the human being and artwork, each understood as a process of self-research and experience-figure, are characterized by a structural correspondence that, considering its difference, gains enormous importance to

\footnotetext{
${ }^{6}$ To get an overview of the most important theories of art that shaped the twentieth century: N.E. Carroll (ed.), Theories of Arts, University of Wisconsin Press, Madison 2000 and S. Davies, Definitions of Art, Cornell University Press, Ithaca, N.Y. 1991.

${ }^{7}$ V. Schürmann, Die Unergründlichkeit des Lebens. Lebens-Politik zwischen Biomacht und Kulturkritik, Transcript, Bielefeld 2011.
} 
the existential relevance of art for human life. This correspondence consists in the fact that both - artwork and person - are distinguished by a constitutive unfathomability. On the basis of this shared unfathomability, I aim to show that the consideration of a work of art for the human being is an excellent way of fulfilling the task of becoming itself. This is possible because the aesthetic experience opens up a space in which the human being is confronted with the same structures, dynamics, and tensions that characterize the process of his own self-researching process. But since the artwork is a product of man, man can take distance to the work of art and reflect on the process of aesthetic experience. This distance enables him to objectify in a certain sense the dynamics of his own process of self-creation and thereby build a conscious relation to himself.

In order to show that, I will first of all address the human life. Based on the new approaches of philosophical anthropology, human life can be defined as the own selfresearch process, characterized by a constitutive unfathomability. In a second step, I will address art and explain that the work of art can also be understood as something unfathomable that form itself during the process of aesthetic experience. By comparing the process of self-research with the process of aesthetic experience, I aim to show in a final section that due the structural similarity of man and the artwork, and yet despite considering their fundamental difference, the aesthetic experience contributes to the success of the self-research process.

\section{The constitutive unfathomability of the human being}

In his apology, Socrates combines the need for self-research with the possibility of being a human being at all ${ }^{8}$. If the possibility of being a man is really to be connected in such necessity to the research of the self, it is surely doubtful. What is certain, however,

\footnotetext{
${ }^{8}$ Plato, Apology of Socrates, ed. by T.G. West, transl. by T.G. West, Cornell University Press, Ithaca N.Y. 1979, pp. 19-20. 
is that self-research - and I am referring to Socrates' search of the self - is the starting point for the question about the human being in the philosophical anthropology of the twentieth century and in the contemporary anthropological approaches. Helmuth Plessner and Arnold Gehlen and, more recently, Emil Angehrn, Gerhard Gamm, and Volker Schürmann are just a few of the classical and contemporary philosophers, who saw in self-research a key phenomenon for understanding human beings in an appropriate way 9 .

This increasing centrality of the motive of the self-research in philosophical anthropology from the twentieth century can be read as an expression of a theoretical change of perspective on life. For self-research gains its relevance for life from the attempt to comprehend human life as an immediate performance of life during this performative process. While in the context of Dilthey's philosophy of life, life understood as the life of the soul, the context of experience and action or the spiritual world - is viewed externally as the object of a theory, philosophical anthropology proceeds from the concrete performative execution of the individual's life. The systematic centrality of the topos of self-research corresponds exactly to the intention to focus on the concrete life of the human being, i.e. the human being, who - as Arnold Gehlen shows - performs his own life and necessarily confronts with its own self ${ }^{10}$. On the basis of the conscious execution of life of each individual, human being is understood as a process of self-understanding and self-realization. It is, among others,

\footnotetext{
9 E. Angehrn, Selbstverständigung und Identität: zur Hermeneutik des Selbst, in B. Liebsch (ed.), Hermeneutik des Selbst - im Zeichen des Anderen: zur Philosophie Paul Ricoeurs, Karl Alber, Freiburg im Breisgau 1999, pp. 46-69; Id. Selbstsein und Selbstverständigung: zur Hermeneutik des Selbst, in E. Angehrn, J. Küchenhoff (eds.), Die Vermessung der Seele: Konzepte des Selbst in Philosophie und Psychoanalyse, Velbrück, Weilerswist 2009, pp. 163-183; Id. Zum Sinn verurteilt. Hermeneutische Spuren der Phänomenologie, in "Studia Philosophica", 73, 2014, pp. 201-219. G. Gamm, Der unbestimmte Mensch. Zur medialen Konstruktion von Subjektivität, Philo, Berlin 2004. V. Schürmann, Unergründlichkeit und Kritik-Begriff. Plessners politische Anthropologie als Ansage an die Schulphilosophie, in "Deutsche Zeitschrift für Philosophie", 45/3, 1997, pp. 345-361; Id. Die Unergründlichkeit des Lebens. Lebens-Politik zwischen Biomacht und Kulturkritik, Transcript, Bielefeld 2011.

${ }^{10}$ The position Gehlen's is particularly interesting in this context, because Gehlen considers the human being from a purely biological perspective and shows that man has a special biological nature. This nature causes that man «um zu existieren, [...] sich zu sich selbst [verhält], lebensnotwendig, wie dies kein Tier tut; er lebt nicht, [...], er führt sein Leben. Nicht aus Spaß, und nicht zum Luxus des Nachdenkens, sondern aus ernster Not». A. Gehlen, Der Mensch. Seine Natur und seine Stellung in der Welt, Klostermann, Frankfurt am Main 2016, p. 12.
} 
Emil Angehrn who, in his ambitious project Hermeneutics of the Self ${ }^{1}$, gives the processes of self-understanding and self-development a fundamental role in the characterization of man. In his texts, he emphasizes again and again that man is an understanding being who has an understanding of his self and makes itself understood: «He [the human being] is the being who asks the question about himself and asks himself what he is, what he wants and what he should do» ${ }^{12}$. And further: «The essence of man is to ask himself these questions. As questions they stand for the definition of man. Man is the being who forever asks about himself - i.e. the question of who he is and who he has to be. It differs from other living beings by this fundamental reflexivity. He has an understanding of himself and communicates with himself ${ }^{13}$.

The decisive factor here is that the process of self-understanding is endless. Again, it is Angehrn who draws attention to the incompleteness and remoteness of selfunderstanding; he refers to an openness, which is constitutive for the process of selfunderstanding and which makes «the self-understanding the path to self-realization (die Selbstverständigung zum Weg der Selbstwerdung)» ${ }^{14}$. The reason for this is that the self that I am forms itself in this infinite process of self-understanding. Man is constantly so to speak becoming himself. By grasping man as such a process, one fundamental feature is expressed: his constitutive unfathomability. For the task of becoming the self comes from the self that has to become. This means that the self is constantly in the process of becoming self-existent and exists only as this process and remains unfathomable to man in his completeness. But every human being is nothing else than his own self. Insofar as the self is unfathomable, man is unfathomable to himself.

The idea of the unfathomability of the self, which has co-established with the topos of self-research, has been interpreted in two different ways.

On the one hand, human life has been defined as unfathomable in reference to the possibility of thinking about it. This view, which Plessner develops on the basis of Dilthey's philosophy of life, is based on the idea that life as a historical and dynamic

\footnotetext{
${ }^{11}$ E. Angehrn, Selbstverständigung und Identität: zur Hermeneutik des Selbst, cit.; Id., Selbstsein und Selbstverständigung: zur Hermeneutik des Selbst, cit.

${ }^{12}$ E. Angehrn, Selbstsein und Selbstverständigung, cit., p. 165 (my translation).

${ }^{13}$ E. Angehrn, Die Fragwürdigkeit des Menschen. Zwischen Anthropologie und Hermeneutik, in I.U. Dalferth, A. Hunziker, Seinkönnen. Der Mensch zwischen Möglichkeit und Wirklichkeit, Mohr Siebeck, Tübingen 2011, pp. 3-18, p. 9.

${ }^{14}$ E. Angehrn, Selbstsein und Selbstverständigung, cit., p. 177 (my translation). 153
} 
context of experience escapes the concept. This idea is expressed by Plessner with the following words:

\begin{abstract}
The unfathomability of the spiritual world is rather based on the methodological principle of the question that aims at understanding. The free acknowledgment of the obligation of the unfathomability opens up the possibility of something like the spiritual world and history, as a life reality, that is newly exhaustible and yet comprehensible, i.e. a life reality that can always be seen as new. And only in the normative acceptance of the unfathomable, which presents itself as a renunciation from the point of view of scientific explanation, in this, if one may, creative renunciation, the spiritual world can be seen as an open reality reaching into our living present and dependent reality appears into sight from its formation through our thinking and acting in every moment in time ${ }^{15}$.
\end{abstract}

This quotation makes two things clear. Firstly, that the unfathomability of life is based on a gap between thought and life, or - which is the same thing - on the difference between the immediacy of life and the mediation of conceptual thought. In other words, the rigidity of conceptual categories does not succeed in grasping the mobility and inexhaustibility of life. Consequently, not only life is determined to be unfathomable, but also unfathomability is understood as the binding principle of any theoretical confrontation with life. Therein lies the second aspect expressed by the quotation: the unfathomability in the sense of Dilthey and Plessner is not for life, but as Plessner remarks elsewhere - «binding for the knowledge of the life of man» ${ }^{16}$. In view of this consideration, the conception of unfathomability can be understood as a concept of reaction resulting from a twofold reaction: the unfathomability of life is, firstly, a response to the inadequacy of an a priori theoretical attempt to understand life that cannot grasp life as a context of experience. And secondly, life is explained as unfathomable in response to the fullness of life in relation to thinking. Life, so to speak, seems to have more imagination than thought, and, hence, is unfathomable to thought.

On the other hand, an immanent perspective on life was assumed and unfathomability was interpreted as a constitutive unavailability, as if self-research were

15 H. Plessner, Macht und menschliche Natur. Ein Versuch zur Anthropologie der geschichtlichen Weltansicht (1931), in G. Dux, O. Marquard, E. Ströker (eds.), Gesammelte Schriften in zehn Bänden V. Macht und menschliche Natur, Suhrkamp, Berlin 2003, pp. 137-234, pp. 181-182 (my translation).

${ }^{16}$ H. Plessner, Macht und menschliche Natur, cit., p. 186. 
concretized in an infinite search for something unavailable, whereby man experiences a continuous defeat ${ }^{17}$.

In my opinion, both interpretations miss the nature of the unfathomability that characterizes man: the first because life is not viewed from an immanent perspective and thus positions the unfathomable in a relationship between life and thought; the second because it implies a separation between self and man and leads to the thesis that man can never really be himself, never really become himself.

I would like to distance myself from both the relativistic and the negative interpretation of unfathomability and rather argue that man - because of his unfathomability - has always been himself because he is constantly coming to himself. This can be shown when self and human being are thought in their identity. For, there is no self to be found outside of this unfathomability. Rather, to understand one's own life-fulfilment as self-exploration means to perceive oneself as an unstoppable constitution of meaning, to understand oneself as a constant tension between immediate execution of life and its consciousness and to consciously stay in this tension without trying to solve it. To be a self, or to become a self, does not mean to overcome the unfathomability of the self in the sense of a process that makes transparent what is initially opaque. Therefore, I would like to distance myself from the meaning of the unfathomable as a synonym of opacity. Rather, becoming a self means becoming aware of one's own constitutive unfathomability, and constantly performing the self search consciously through the immediate performance of life, and, simultaneously, as contradictory as it may sound, to be conscious of the tension of the conscious immediacy. The inherently open character of this tension, which can be metaphorically described as the space of the individual's own execution of life, constitutes the constitutive unfathomability of man.

These considerations show that man, insofar as he is conceived as the open, conscious process of his self-realization, is distinguished by a constitutive unfathomability.

\section{The constitutive unfathomability of the artwork}

\footnotetext{
${ }^{17}$ V. Schürmann, Die Unergründlichkeit des Lebens, cit. 155
} 
As Stephen Halliwell notes, Western thought is characterized by two fundamental ideas about art, which are based on the combined approaches of Plato and Aristotle. Both ideas are to be understood in relation to Mimesis as a mimetic process. The first idea considers art as a copy of the world as it is. The second one regards art as an autonomous world, in which our way of knowing and understanding things are simulated. ${ }^{18}$ But whit the so-called autonomous art, established in the eighteenth century, the idea of art as an imitation loses its naturalness, and questions about the nature of art and its significance for life become problematic. As a result, a stronger relationship between philosophy and art develops. Art seems to need thought, and thought endeavours to deal with art systematically.

Although Wolfgang Welsch's theses that «art is as an emergency helper of philosophy in terms of unity» ${ }^{19}$ and that «art has become the object of demonstration of superiority in philosophical comprehension» ${ }^{20}$ are controversial, one certainly agrees with him that the fact that «art requires aesthetics is a specific modern conception and constellation ${ }^{21}$. The theoretical confrontation with art and their organic integration into the thought systems of Emmanuel Kant, Friedrich Schiller, Friedrich W.J. Schelling or Georg W.F. Hegel prove the reciprocal need of art and thought. At the same time, they express the firm conviction that the question What is art? can be adequately answered through thinking. As even Welsch rightly notes, however, a certain inadequacy of thinking about art is already being anticipated in Romanticism. Prominent philosophers, such as Schiller, Gotthold E. Lessing, and Friedrich Schlegel, express their scepticism regarding the possibility of an aesthetics that does justice to art. One of Schiller's letters reads: «From art philosophy, no way leads to the object. The philosophy of art is an empty metaphysical chatter» ${ }^{22}$. Lessing, too, expresses his scepticism towards aesthetics: «Reasoning about art from merely general concepts can lead one to crickets,

\footnotetext{
${ }^{18}$ S. Halliwell, The Aesthetics of Mimesis, Princeton University Press, Princeton 2002, p. 5.

19 W. Welsch, Philosophie und Kunst - Eine wechselhafte Beziehung. Philosophy and Art - An Ambiguous Relationship, in his Aesthetics and Beyond, Jilin People's Publishing House, Changohun, PR China 2007, pp. 78-97, p. 82.

${ }^{20} \mathrm{Ivi}, \mathrm{p} .86$.

${ }^{21} \mathrm{Ivi}$, p. 80.

${ }^{22}$ F. Schiller, Über die ästhetische Erziehung des Menschen in einer Reihe von Briefen, in Id., Sämtliche Werke 5, ed. by G. Fricke, H.G. Göpfert, 6en edn, Hanser, München 1980.
} 
which one finds for long or short, refuted to his shame, in the works of art» ${ }^{23}$. And Schlegel even asserts the impossibility of a philosophy of art: «In what is called philosophy of art, usually one of them is missing, either philosophy or $\operatorname{art}^{24}$.

This doubt regarding the possibility of a theoretical conception of art intensifies in the twentieth century. Paradigmatic for this are the Neo-Wittgensteinian Theories: based on Wittgenstein's concept of family resemblance, authors like Morris Weitz, William Kennick, and Paul Ziff ${ }^{25}$ argue that it is impossible to find a definition of art, which indicates sufficient and necessary conditions to determine the art-status of an object. Although the Neo-Wittgenstein paradigm was rightly criticized and therefore overcome, the question of what is art? and, consequently, the question of its relevance for life still cause discomfort even today.

The attempt to develop a universal definition of art nowadays seems a challenging and even presumptuous aim. The fact that a theory of art seems impossible is neither merely an expression of a pluralistic world nor an expression of different approaches to the same object or practice of art. Furthermore, this plurality of definitions and experimentations cannot be traced back to the new forms of artistic expression that elude the categorical apparatus of the aesthetics of works, from «open works of art (opera aperta)» ${ }^{26}$ to «works of art in motion» ${ }^{27}$. The plurality of theories in the field of art seems to be tied to the nature of art itself. The current aesthetic theory, which is limited to a consideration of art, shows how historical and cultural aspects must become necessary components of an aesthetic theory that does not want to be banal. That is to say, in attempting to define a work of art, one should renounce any claim to universality and take into account the conditions under which something - be it an object in the case of a classical work of art or a phenomenon in the case of an expression of the performance art - can be defined as a work of art. The debate between Arthur Danto

\footnotetext{
${ }^{23}$ G.E. Lessing, Laokoon oder über die Grenzen der Malerei und Poesie, in Id., Lessings Werke 3, ed. by K. Wölfel, Insel, Frankfurt am Main 1967, pp. 7-171, p. 150.

${ }^{24}$ F. Schlegel, Lyceums-Fragmente, in Id., Kritische Ausgabe 3, ed. by E. Behler, Schöningh, München 1967, pp. 147-163, p. 148.

${ }^{25}$ M. Weitz, The Role of Theory in Aesthetic, cit.; W. Kennick, Does Traditional Aesthetics Rest on a Mistake, cit.; P. Ziff, The Task of Defining a Work of Art, cit.

${ }^{26}$ U. Eco, Opera aperta. Forma e indeterminazione nelle poetiche contemporanee, Bompiani, Milano 1962.

${ }^{27}$ U. Eco, Opera aperta, cit., p. 42.
}

157 
and Noël Carroll about the artwork-status of Andy Warhol's Brillo Box is paradigmatic in this sense $e^{28}$.

Despite the many profound differences that characterize many of the theories of art, they share a common trait: the point of departure for the consideration of art is no longer art at all, but the individual artwork. Nelson Goodman's proposal to replace a substantialist with a functionalist perspective is one of the most significant attempts in this sense. Based on the question When is art? Goodman understands the artwork as something that fulfils a certain function, and indeed a sign-function ${ }^{29}$. But - as Lambert Wiesing shows ${ }^{30}$ - even this perspective does not seem to do justice to the artwork and the claim of autonomous art to be completely independent of any possible function: If, on the one hand, such an understanding of art bypasses the problems of a work aesthetics, it prepares, on the other hand, new difficulties. For the characteristics of a sign consist precisely in not focusing attention on itself, but on the signified. This implies, however, that the sign as such need not be noticeable. The artwork as a sign therefore becomes transparent to the observer and dependent on the signified.

Following Sartre, who develops an artistic concept that at the same time overcomes the difficulties of both a materialist and a functionalist consideration of art, I will argue that it is possible to obtain an appropriate definition of art only if the work of art is understood as an experience-figure. In his treatise Qu'est-ce que la littérature $?^{31}$ (1948) Jean-Paul Sartre describes a work of art as an imaginary object, which arises only in the appreciation of art:

\footnotetext{
And it is one thing to work with colour and sound, and another to express oneself by means of words. Notes, colours, and forms are not signs. They refer to nothing outside themselves [...] There is green, there is red, and that is all. They are things, they exist by themselves. It is true that one might, by convention, confer the value of signs upon them. Thus, we talk of the language of flowers. But if, after the agreement, white roses signify 'fidelity' to me, the fact is that I have stopped seeing them as roses. My attention cuts through them to aim beyond them at this abstract virtue. I forget them. I no longer pay attention to their mossy
}

\footnotetext{
${ }^{28}$ N. Carroll (ed.), Theories of Art Today, cit., pp. 13-15; A.C. Danto, Art and Meaning, in N. Carroll, Theories of Art Today, cit., pp. 130-140.

${ }^{29}$ N. Goodman, Ways of Worldmaking, Hackett Publishing Company, Indianapolis 1978, pp. 57-70.

${ }^{30}$ L. Wiesing, Phänomenologie und die Frage 'Wann ist Kunst?', in G. Pöltner, Phänomenologie der Kunst. Wiener Tagung zur Phänomenologie, 1999, Lang, Oxford 2000, pp. 131-152, pp. 135-136.

${ }^{31}$ J.-P. Sartre, Qu'est-ce que la littérature?, Gallimard, Paris 1948.
} 
abundance, to their sweet stagnant odour. I have not even perceived them. That means that I have not behaved like an artist. For the artist, the colour, the bouquet, the tinkling of the spoon on the saucer, are things, in the highest degree. He stops at the quality of the sound or the form. He returns to it constantly and is enchanted by it. It is this colour-object that he is going to transfer to his canvas, and the only modification he will make it undergo is that he will transform it into an imaginary object. He is therefore as far as he can be from considering colours and signs as a language ${ }^{32}$.

The artwork is therefore not the material object that is made by the artist as an object. Rather, the artwork is the object that arises only from consideration. This item does not have material properties: it is present but not real; it is imaginary. Sartre therefore characterizes the work of art neither by signs nor by meanings, but by the creation of reality, which can be grasped as an absolute, unexplainable reality. The artwork is therefore not the material object that is made by the artist., rather, the artwork is the object that arises only through the aesthetic experience of the viewer. This object does not have material properties: it is present but not real; it is imaginary. The work of art is therefore characterized by Sartre neither by signs nor by meanings, but by the creation of reality, which can be grasped as an absolute, unexplainable reality.

This idea can be illustrated in reference to Gadamer's essays on art published in the late 1970 s, in which he takes up the imaginary reality created from the perspective of the symbol. Unlike his remarks of the 1960s, which understand art as a statement and context of meaning, in Die Aktualität des Schönen ${ }^{33}$ (1974) Gadamer leads his hermeneutic interpretation of art over the symbol concept ad absurdum. Art - Gadamer says - is a symbol. But he warns against a classical understanding of symbol as a concept, which creates a connection between two separate aspects of the symbolic relationship: «The symbolic representation that art makes does not require any particular dependence on given things. [...][art] brings something to representation. But we must guard against the misunderstanding of thinking that this something is presented here could still be grasped in another way, and 'there' also by the fact that it presents itself in such a linguistic way» ${ }^{34}$. And further: «Symbolic has to be understood in the

\footnotetext{
${ }^{32}$ J.-P. Sartre, Qu'est-ce que la littérature?, pp. 12-13 (my translation).

33 H.G. Gadamer, Die Aktualität des Schönen, in Id. Ästhetik und Poetik I: Kunst als Aussage, Gesammelte Werke 8, Mohr, Tübingen 1993, pp. 94-142.

${ }^{34} \mathrm{Ivi}, \mathrm{p} .127$. 
sense that in the work of art not only is something referenced, but that this reference is present in the artwork. In other words: the artwork is an increase in being» ${ }^{35}$.

Sartre's and the late Gadamer's short descriptions of art give rise to two important aspects that make possible a unified definition of the artwork that takes into account the uniqueness of each work of art and, at the same time, fulfils the demand of autonomous art. On the one hand, this conception of art shows that as soon as the attempt is made to think about art and art of the artwork, the work of art manifests itself as something unfathomable. It defies every conceptual definition. The artwork is neither sign nor matter, neither word nor symbol. The terms used by Sartre and Gadamer to name this something - object, representation, symbol - fulfil their purpose only insofar as they deny and refute their nature: the object is unreal, the representation imaginary, the symbol absolute. On the other hand, the two views of art show that this unfathomability, which constitutes the work of art cannot be thought of as something outside the process of aesthetic experience: the work of art becomes the unfathomability that it is only through the experience of a viewer and during this experience.

These considerations show that the artwork, insofar as it is conceived as the open process of its self-realization, is distinguished by a constitutive unfathomability.

This characterization of the unfathomability of the work of art has remarkable similarities with the constitutive unfathomability of the human being. For even man as unfathomable can only be understood as a process of self-realization that unfolds during this process. But works of art are not people. As banal as this statement may seem, the existential relevance of art for life can be explained only by this difference.

In the next and final section of my essay, I will show - based on the analogy between man and the work of art while at the same time considering their difference - how art can contribute to the fulfilment of the process of becoming a human being.

\section{Self-research and aesthetics experience}

Human being and the work of art are unfathomabilities that unfold during processes. Both can be described as unstoppable processes of self-realization. Of course, beyond this common aspect there is a fundamental difference between these processes: one -

\footnotetext{
${ }^{35}$ Ivi, p. 126.
} 
the process of self-realization of man - is completely independent in relation to the possibility of the self-realization-process of the work of art. It is only determined by the person who becomes in the process who he is. The other process - the process of aesthetic experience -, which makes a work of art what it is, requires the human being in order to be able to be performed. Even as unfathomable, the work of art can only be thought of in relation to a man and manifests itself as a human product.

This difference makes it possible to explain the relevance of art for the process of becoming one's self. To decipher this relevance, I will discuss the similarities between the processes of aesthetic experience and self-research.

The first common aspect of the self-research process and aesthetic experience is that both processes are self-creating. Since both are referring to the self-research and the aesthetic experience, an analogy can be established between the starting point and the result of the respective processes. For the human being becomes what it is through the self-research process. Similarly, through the aesthetic experience, the artwork becomes what it is. Man and the artwork do not exist outside the particular process of selfresearch and aesthetic experience. They become what they are only through these processes and while the processes are being performed. Self-research and aesthetic experience thus contain their own purpose and can therefore be explained as processes that have their end in themselves.

The fact that these two processes are self-creating does not mean that they are not leading to something new. On the contrary, self-research and aesthetic experience bring about the emergence of something new and unforeseeable. The endless process of becoming a human being always makes of the person who is identical with its own selfresearch process a new person. Man constantly recreates itself. Likewise, something new arises through the aesthetic experience, namely a non-material reality that has no existence outside of experience. From this, the second common aspect of self-research and aesthetic experience can be deduced: both are creative processes.

The third thing they share is that both processes give rise to unfathomable things that are beyond any possible definition. A work of art that is experienced cannot be expressed entirely in words or even put into words, cannot be inserted into existing contexts of meaning, and in no way fully understood. At every point in his life, man can only be understood as an unfathomable self. The impossibility of fully grasping people 161 
and artworks by thinking does not mean that they are completely inaccessible to humans and therefore meaningless. For in both cases we recognize their unrepeatability, irreplaceability, and their unique individuality.

Following this, the fourth and final common aspect of self-research and aesthetic experience can be opened up: both processes create something unique. The reason for this is that both processes unfold according to a logic that is inherent in every single process and therefore creates something unique. But this highest individuality cannot be expressed through qualities. The only way we human beings know to name and recognize the uniqueness of singular individuals by their proper name. Proper names name the unnameable, they name the constitutive unfathomability of a human being. It may not be a coincidence that works of art are human products that, like humans, have proper names. Man tries, as is the case with other human beings, to name the unique unrepeatability of the work of art.

From this confrontation between the process of self-research and the aesthetic experience follows that both processes are distinguished by their own purposefulness and creative power, and that their products lend themselves to unfathomability and uniqueness.

These similarities show that in the process of aesthetic experience - during the encounter with a work of art - a person is confronted with a process that is structurally very similar to that of becoming one's self. But the experience that he or she makes with the work of art, i.e. that the work of art is the product of man and therefore something other than man, can be objectified.

The person, who as a viewer is completely involved in the encounter and unfolding of the artwork during the aesthetic experience, can subsequently objectify this experience and reflect on it. He can look at himself during an encounter with unfathomability that is structurally very similar to his own unfathomability. In doing so, he sees that he has lingered on the work of art in order to create the unfathomable work of art; he became involved in the work of art and that no particular expectation of meaning has guided either his experience or his thinking. The attitudes, dynamics, and processes that have led him to unravel the artwork become transparent to the viewer. In this way, he becomes aware of how he has gained access to the unfathomability of the 
artwork and thereby becomes aware of how he can gain access to his own unfathomability in a similar way.

Yet, looking at art not only gives man access to his own self, but by reflecting on the experience of a work of art, the viewer becomes aware that he has remained in tension through which the space between immediate experience and conceptual thinking has arisen and which constitutes the unfathomability of the work of art as well as his own unfathomability. He can therefore objectivize the inconceivable space through the aesthetic experience and observe himself in this space. Through aesthetic experience, therefore, man can also learn how he can remain in the space of his own performance of life, by which he constantly becomes what he is.

By succeeding in the encounter with a work of art, the consideration of art also creates the hope that the process of becoming one's self can be successful. For the aesthetic experience proves that something unforeseeable can emerge; it proves that unfathomability unfolds and shows. Through consideration of art man gains confidence in the possibility of being able to constantly fulfill the infinite task of becoming itself.

\section{Conclusion}

As anticipated in the introduction to this paper, the present analysis differs from the interests and contents of current aesthetic research, both in the Anglo-American world and in the European context. The central question does not concern the criteria according to which it is possible to attribute the artwork-status to an object and therefore the criteria according to which it is possible to differentiate between art and non-art. Nor does it question all those changes in the aesthetic environment that extend the strictly artistic sphere and are intertwined with the interests of research on nature, politics, economics, engineering and the world of life in general. Nor is the primary interest of the paper constituted by all those changes in aesthetics that broaden the research fields and are intertwined with the interests of other sciences, such as politics, economics, sociology, environmental ethics, engineering, etc.

The attempt of this article is to show that the work of art - whether it is defined in essentialist terms, as an open concept, as a purely social fact, on an intentional basis or according to historical narrative criteria, can have an existential relevance for human 
life. This potential is not based on its content, but on a structural similarity between the nature of the work of art and human life. A similarity that emerges - beyond the different aspects of all possible definitions - if one chooses an immanent access to the work of art and to life, that is, if the work of art is considered as unique experiencefigure and the human life as life-performance of the individual human being.

The existential importance that art can have for life is based on the possibility of objectifying the process of aesthetic experience, which structurally resembles the selfresearch process: the possibility that man's dynamics and structures of the self-research process become apparent; the possibility of access to something that, like man himself, is unfathomable; the possibility of lingering in space arising from the tension between reflection and immediate action; and, not least, the emergence of trust in dealing with an unfathomability; these are the characteristics that - when life is examined starting from the concrete life-performance of each individual and art starting from the work of art explain and characterize the existential relevance of the encounter of art for human beings.

The aesthetic experience that makes the work of art the unique unfathomability that it is, therefore, reveals itself as an excellent path to the process of self-research, which makes man the unique unfathomability that he or she is. 